\title{
RESULTS OF INDOOR RADON MEASUREMENTS IN THE REPUBLIC OF MACEDONIA: - A REVIEW -
}

\author{
Zdenka Stojanovska' ${ }^{1}$, Blažo Boev², Ivan Boev² \\ ${ }^{1}$ Faculty of Medical Sciences, Goce Delčev University, Štip, Republic of Macedonia \\ ${ }^{2}$ Faculty of Natural and Technical Sciences, Goce Delčev University, Štip, Republic of Macedonia \\ e-mail: blazo.boev@ugd.edu.mk
}

\begin{abstract}
Radon and its short lived decay products accumulated in indoor environment are the main source of public exposure to natural radiations. The health effects as well as a great number of natural and artificial factors affecting the radon accumulation in indoor environments are some of the motives for the scientific interest in radon issue. Following this global trend, many studies of indoor radon in the Balkan region, including the Republic of Macedonia have been conducted in the last decade. This paper is an overview of the published papers regarding indoor radon concentration measurements with nuclear track detectors in the Republic of Macedonia. It gives basic information about the spatial and temporal variability of indoor radon over the territory of the country, following by a description of the some factors which affect its variations. This review attempts: to organize available indoor radon results in order to show clear picture of the so far conducted surveys; to highlight the need for continuation of more extensive radon investigation in workplaces; to motivate the building professionals to create as much as possible mitigation methods for indoor radon reduction, to motivate the health professionals for epidemiological studies etc.
\end{abstract}

Key words: indoor radon; spatial variations; temporal variations; geology; building characteristics

\section{INTRODUCTION}

Radon $\left({ }^{222} \mathrm{Rn}\right)$ is a radioactive, noble gas produced by the decay of ${ }^{226} \mathrm{Ra}$ contained in all terrestrial materials. Both of them originate from ${ }^{238} \mathrm{U}$ decay chain. Radon decays with 3.8 days half-life by alpha particle emission followed by a chain of subsequent short lived decay products: ${ }^{218} \mathrm{Po}\left(\mathrm{T}_{1 / 2}=\right.$ $3.05 \mathrm{~min}),{ }^{214} \mathrm{~Pb}\left(\mathrm{~T}_{1 / 2}=26.8 \mathrm{~min}\right),{ }^{214} \mathrm{Bi}\left(\mathrm{T}_{1 / 2}=19.7\right.$ $\min )$ and ${ }^{214} \mathrm{Po}\left(\mathrm{T}_{1 / 2}=164 \mu \mathrm{s}\right)$.

Radon and its decay products accumulated in indoor environment are the main natural source of total public exposure to ionizing radiation (UNSCEAR, 2000). Some epidemiological studies have proven the association between the chronic exposure to high indoor radon concentrations $\left(C_{\mathrm{Rn}}\right)$ and the incidence of lung cancer (Darby et al., 2005). Considering serious health effects, the preparation and implementation of a national radon program (NRP), which main goal is the reduction of the radon risk, becomes a primary task in most countries over the world. The NRP involves a complex organizational structure that includes components for radon monitoring, prevention and mitigation of increased $C_{\mathrm{Rn}}$ (WHO, 2009). Its preparation requires a multidisciplinary approach conditioned by the understanding of the radon processes in indoor environment.

The source of indoor radon is the radium present in soil and building materials (UNSCEAR, 2000). After its generation, radon emanates from solid grains and transported through porous media until its exhalation from the surface into atmosphere or into indoor environment. Diffusion and advection are the radon transport mechanisms driven by the concentrations and pressure gradients, respectively. In general radon dynamics is complex and depends on many factors resulting in the high variability of radon concentration in indoor air.

The factors that influence the $C_{\mathrm{Rn}}$ variation could be classified into three groups: geogenic 
radon potential (GRP), building characteristics and building users lifestyle (habits). GRP is a factor that relates building underlying geology and $C_{\mathrm{Rn}}$. The GRP is explained through the soil gas radon concentration and soil permeability. The soil gas radon concentration depends on the ${ }^{226} \mathrm{Ra}$ specific activity in the soil, which is proven to be in relation with geology. Permeability of the soil is another key geological factor that primarily affects the dynamics of radon in the soil gas as well as its emanation from the soil surface. The density of infiltrated radon flux from the soil, as well as accumulated radon concentration in the building, depends on the characteristics of the building. In the following, different habits of building inhabitants which relate to diverse levels of room ventilation (windows opening) is in function of the inhabitant's lifestyle, but also with meteorological conditions (among other: Yarmoshenko et al., 2016; Nikolopoulos et al., 2014).

The meteorological conditions also significantly affect the radon dynamics resulting in temporal variability of $C_{\mathrm{Rn}}$. Just like the meteorological parameters, the indoor radon concentrations are subject to daily, weekly, monthly and seasonal variation (Kolarž et al., 2017; Nafezi et al., 2014; Ćurguz et al., 2013; Vaupotič, 2012; Vaupotič et al., 2008; Stojanovska et al., 2011). Because of that, the requirements are to present $C_{\mathrm{Rn}}$ in a building as annual $C_{\mathrm{Rn}}$.

The awareness of the potential health problems that could be caused by the increased $C_{\mathrm{Rn}}$, led to gradual growing of the investigations of indoor radon over last decades. As in the rest of the world, a large number of scientific works the Balkans, including the Republic of Macedonia, have been done. The papers that appeared in the literature are mainly related to radon sources, radon measurements and are focused as well on factors that affected radon variability (such as: Žunić et al., 2017a, 2017b, 2014, 2013, 2010, 2007; Ivanova et al., 2016; Vucković et al. 2016; Bochicchio et al., 2014; Vaupotič at al., 2013, 2008; Carpentieri et al., 2011).

This study summarized the results of indoor radon concentrations $\left(C_{\mathrm{Rn}}\right)$ in the Republic of Macedonia published in the literature. These results are based on radon measurements in 520 dwellings, 74 schools and 5 kindergartens. Discussion is oriented to radon spatial variations, the effect of buildings characteristics on radon variation, as well as to seasonal variations. The measured data is also compared with reported data for some countries in the Balkan region.

\section{MATERIAL AND METHODS}

\section{Study area}

The Republic of Macedonia is situated in the central part of the Balkan Peninsula (Southeastern Europe), covering an area of $25.713 \mathrm{~km}^{2}$. Its geographical position is shown on the left maps in Figure 1 . The territory is organized into 84 municipalities contained in eight statistical regions (separated with lines in Figure 1), with a total population of 2.022.547 (State Statistical Office, 2002).
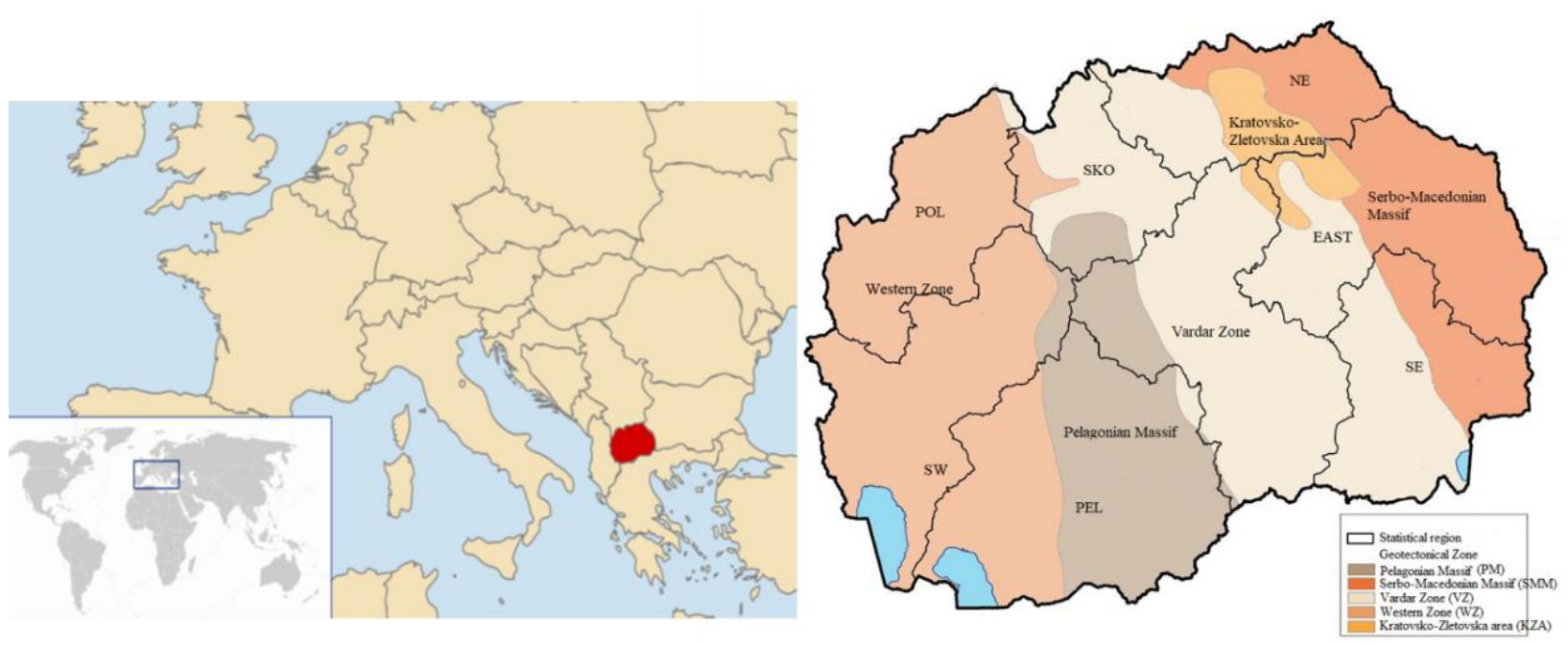

Figure 1. Left two maps: Geographical position of the Republic of Macedonia. Right map presents four Geotectonical Zones and one area within the country coloured with different colours. The territory is organized in 8 statistical regions where the names are coded with capital letters: Skopje (SKO), Polog (POL), Southwest (SW), Pelagonia (PEL), Northeast (NE), East (East). 
The area is described by complex geotectonic features of diverse relief and a complex geology. It is broadly divisible into four geotectonic units: Western Macedonian zone, Pelagonian massif, Vardar zone and Serbo-Macedonian massif and a separate Kratovsko-Zletovska volcanic rock area situated between the Vardar zone and the SerboMacedonian massif (five different colored in Figure 1). The entire territory has a transitional climate, from Mediterranean to continental.

\section{Radon measurements}

In general, the $C_{\mathrm{Rn}}$ measuring methods are active or passive. There is also a consequent application depending on the goals of the measurements. So, the active methods are used to make short term measurements and they are applied in cases when quickly respond to $C_{\mathrm{Rn}}$ is needed in some building or to examine radon dynamics for a certain relative- ly short period of time. The passive techniques are time integrated methods in which $C_{\mathrm{Rn}}$ is measured by nuclear track detectors, exposed over longer period usually in 3, 6 or 12 months. Detector response (calibrated in $\mathrm{Bq} / \mathrm{m}^{3}$ ) presents the average $C_{\mathrm{Rn}}$ for a certain period. The main advantage of this technique is the possibility to perform simultaneous $C_{\mathrm{Rn}}$ measurements in many buildings in a particular region.

According to the goals of the four radon surveys performed in Macedonia, all measurements were made using passive nuclear track detectors. The survey code, study area, type of environment with the number of buildings considered in the survey, floor level, detector commercial name, as well as the period of detector exposure for each survey separately are given in Table 1.

The principle of detection, as well as the results processing procedures of the measured concentrations, are explained in detail in the cited references in Table 1.

Table 1. Basic information for applied methodology in four $C_{\mathrm{Rn}}$ surveys in the Republic of Macedonia

\begin{tabular}{|c|c|c|c|c|c|c|}
\hline $\begin{array}{l}\text { Survey } \\
\text { code }\end{array}$ & Study area & $\begin{array}{l}\text { Type of envi- } \\
\text { ronment (num- } \\
\text { ber of buildings) }\end{array}$ & Floor level & $\begin{array}{l}\text { Detector } \\
\text { commercial } \\
\text { name }\end{array}$ & $\begin{array}{l}\text { Detector } \\
\text { exposure }\end{array}$ & Reference \\
\hline S1 & $\begin{array}{l}\text { Whole country } \\
\text { territory }\end{array}$ & Dwellings (437) & $\begin{array}{l}\text { Ground, } \\
\text { First } \\
\text { Second }\end{array}$ & $\begin{array}{l}\text { RSKS, } \\
\text { RADUET }\end{array}$ & $\begin{array}{l}4 \text { successive } \\
\text { seasons (De- } \\
\text { cember } 2008 \text { to } \\
\text { November 2009) }\end{array}$ & $\begin{array}{l}\text { Stojanovska, } \\
2011 \mathrm{a} \\
\text { Stojanovska, } \\
2011 \mathrm{~b}\end{array}$ \\
\hline $\mathrm{S} 2$ & $\begin{array}{l}\text { Five municipali- } \\
\text { ties in Vardar } \\
\text { zone }\end{array}$ & Schools (43) & Ground & $\begin{array}{l}\text { TASTRAK } \\
\text { RADUET }\end{array}$ & $\begin{array}{l}3 \text { months in } \\
\text { spring of } 2012\end{array}$ & $\begin{array}{l}\text { Stojanovska, } \\
2014\end{array}$ \\
\hline S3 & $\begin{array}{l}\text { Two municipali- } \\
\text { ties in Kratovsko } \\
\text { Zletovska area } \\
\text { and one in Var- } \\
\text { dar zone }\end{array}$ & $\begin{array}{l}\text { Dwellings (40), } \\
\text { schools (31), } \\
\text { kindergarten (5) }\end{array}$ & Ground & $\begin{array}{l}\text { RSKS, } \\
\text { Gamma } 1\end{array}$ & $\begin{array}{l}\text { Annual (from } \\
\text { June } 2013 \text { to } \\
\text { May 2014) }\end{array}$ & $\begin{array}{l}\text { Stojanovska, } \\
2016 \mathrm{a} \\
\text { Stojanovska, } \\
2016 \mathrm{~b}\end{array}$ \\
\hline S4 & $\begin{array}{l}\text { Whole country } \\
\text { territory }\end{array}$ & Dwellings (43) & Ground & RSKS & $\begin{array}{l}3 \text { months in win- } \\
\text { ter of } 2013\end{array}$ & $\begin{array}{l}\text { Stojanovska, } \\
2017\end{array}$ \\
\hline
\end{tabular}

\section{Design of surveys}

The purpose of the first survey, marked by $\mathrm{S} 1$ in Table 1, was to established the basic map of the annual $C_{\mathrm{Rn}}$ distribution across the whole country territory (Stojanovska et al., 2011a). Seasonal variations of $C_{\mathrm{Rn}}$ were also studied (Stojanovska et al. 2011a). To that end, the detectors were deployed in the dwellings on the whole territory of the country. The number of detectors in each municipality was determined in dependence of the population density. The $C_{\mathrm{Rn}}$ was measured in 4 consecutive seasons, so the annual $C_{\mathrm{Rn}}$ was calculated as arithmetic mean of the 4 measurements.
In order to investigate the $C_{\mathrm{Rn}}$ variability in primary schools, the S2 survey was conducted in 5 municipalities in the geotectonical Vardar zone. The measurements were done in the spring of 2012 and the annual concentration was assessed using seasonal correction factors (Stojanovska et al., 2011b).

The third S3 survey, was conducted in 3 municipalities, one in the geotectonical Vardar zone and the other two in the Kratovo-Zletovska area. The detectors were deployed in the dwellings, primary schools and kindergartens and exposed for a period of one year.

The fourth research (S4) deals with the seasonal variability of $C_{\mathrm{Rn}}$ and the effects of 
seasonal correction on the spatial variability of annual $C_{\mathrm{Rn}}$ and its uncertainty. The detectors were exposed during the winter period in 2013, in the dwellings throughout the whole territory of the country. The annual $C_{\mathrm{Rn}}$ was estimated according to the linear model developed in this study.

In all surveys and for each building, the measurements were made in one of the mostly occupied rooms: a living room or bedroom in the dwellings, classroom in the schools, and a playroom or bedroom in kindergartens.

\section{RESULTS}

The maximum value (Max), the arithmetic mean (AM), the standard deviation (SD), variation coefficient $(\mathrm{CV}=\mathrm{SD} / \mathrm{AM})$, the geometric mean (GM) and geometric standard deviation (GSD) of the annual mean radon concentrations, as well as the number (percent) of buildings where indoor radon concentrations exceed national action level of 400 $\mathrm{Bq} / \mathrm{m}^{3}$ for existing buildings, are given in Table 2.

Table 2. Basic descriptive statisticc of annual radon concentrations measured in 4 radon surveys in the Republic of Macedonia

\begin{tabular}{lccccccc}
\hline \multirow{2}{*}{$\begin{array}{l}\text { Survey } \\
\text { code }\end{array}$} & $\begin{array}{c}\text { Max } \\
\left(\mathrm{Bq} / \mathrm{m}^{3}\right)\end{array}$ & $\begin{array}{c}\mathrm{AM} \\
\left(\mathrm{Bq} / \mathrm{m}^{3}\right)\end{array}$ & $\begin{array}{c}\mathrm{SD} \\
\left(\mathrm{Bq} / \mathrm{m}^{3}\right)\end{array}$ & $\begin{array}{c}\mathrm{CV} \\
(\%)\end{array}$ & $\begin{array}{c}\mathrm{GM} \\
\left(\mathrm{Bq} / \mathrm{m}^{3}\right)\end{array}$ & GSD & $\mathrm{N}(\%)>400 \mathrm{~Bq} / \mathrm{m}^{3}$ \\
\hline S1 & 720 & 105 & 84 & 80 & 84 & 1.9 & $(1.8 \%)$ \\
S2 & 260 & 94 & 54 & 57 & 82 & 1.7 & - \\
S3 & 990 & 186 & 178 & 95 & 131 & 2.34 & $7(9 \%)$ \\
S4 & 460 & 120 & 85 & 69 & 98 & 1.9 & $1(2 \%)$ \\
\hline
\end{tabular}

The mean values in the $\mathrm{S} 1, \mathrm{~S} 2, \mathrm{~S} 3$ and S4 studies expressed through $\mathrm{AM}$ and $\mathrm{GM}$ were in intervals from $94 \mathrm{~Bq} / \mathrm{m}^{3}$ to $186 \mathrm{~Bq} / \mathrm{m}^{3}$ and from 82 $\mathrm{Bq} / \mathrm{m}^{3}$ to $131 \mathrm{~Bq} / \mathrm{m}^{3}$, respectively. The $C_{\mathrm{Rn}}$ variations in each of them indicated by $\mathrm{CV}$ and GSD covered intervals: from $57 \%$ to $95 \%$ and from 1.7 to 2.34 .

\section{Building factors affecting radon variability}

The GMs of annual $C_{\mathrm{Rn}}$ measured on the different floors in S1 survey in comparison with GM of annual $C_{\mathrm{Rn}}$ measured on ground floors in other three surveys are presented in Figure 2.

The GMs of $\mathrm{C}_{\mathrm{Rn}}$ (with GSD in brackets) measured on ground, first and second floor in $\mathrm{S} 1$ were: 98 (1.9) $\mathrm{Bq} / \mathrm{m}^{3}$, 66 (1.7) $\mathrm{Bq} / \mathrm{m}^{3}$, 57 (1.6) $\mathrm{Bq} / \mathrm{m}^{3}$, respectively. The $\mathrm{GM}$ values which represented S2, S3 and S4 surveys in Figure 2 are the same values given in the Table 2, respectively, since all measurements in that surveys were performed on the ground floors.

Figure 3 shows the GMs of annual $C_{\mathrm{Rn}}$ grouped according to the presence or absence of basement in buildings where measurements were done. The GMs of annual $C_{\mathrm{Rn}}$ (with GSD in brackets) in buildings with basement: $73(1.8) \mathrm{Bq} / \mathrm{m}^{3}, 83$ (2.10) $\mathrm{Bq} / \mathrm{m}^{3}$, 71 (1.65) $\mathrm{Bq} / \mathrm{m}^{3}$, and without base-

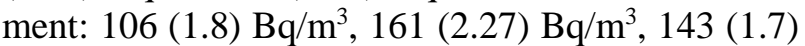
$\mathrm{Bq} / \mathrm{m}^{3}$ were obtained in S1, S3 and S4 surveys, respectively.

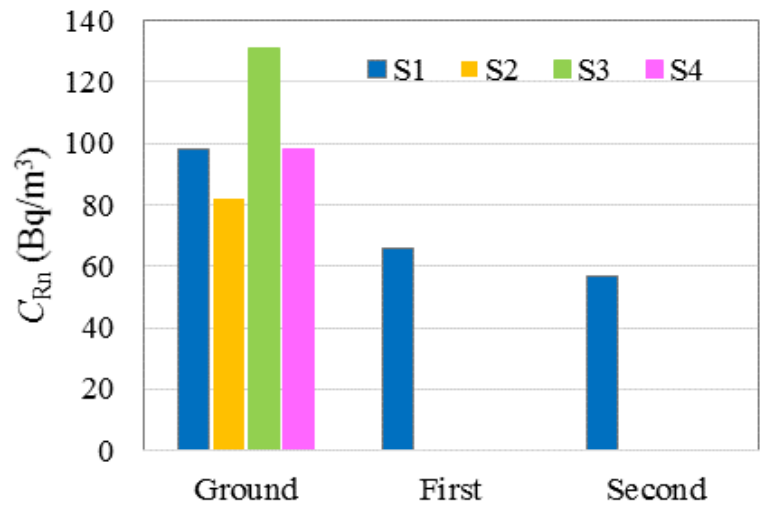

Figure 2. GM of annual $\mathrm{C}_{\mathrm{Rn}}$ measured in different building floors

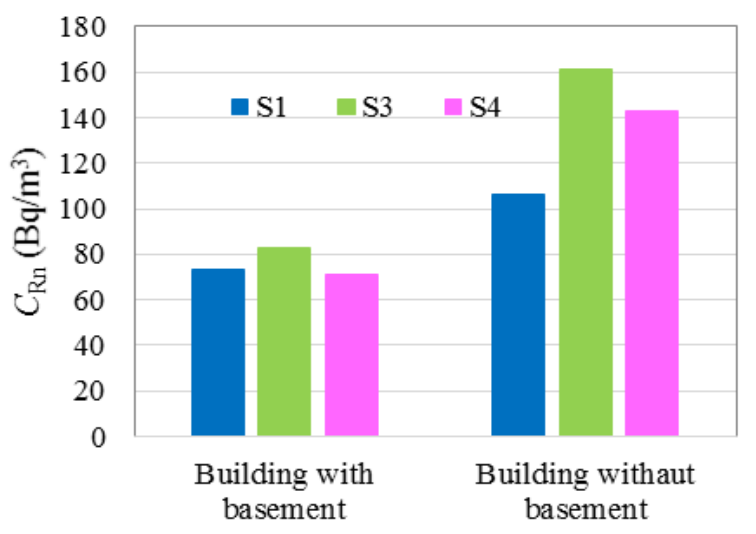

Figure 3. GMs of annual $C_{\mathrm{Rn}}$ measured in buildings with and without floor 


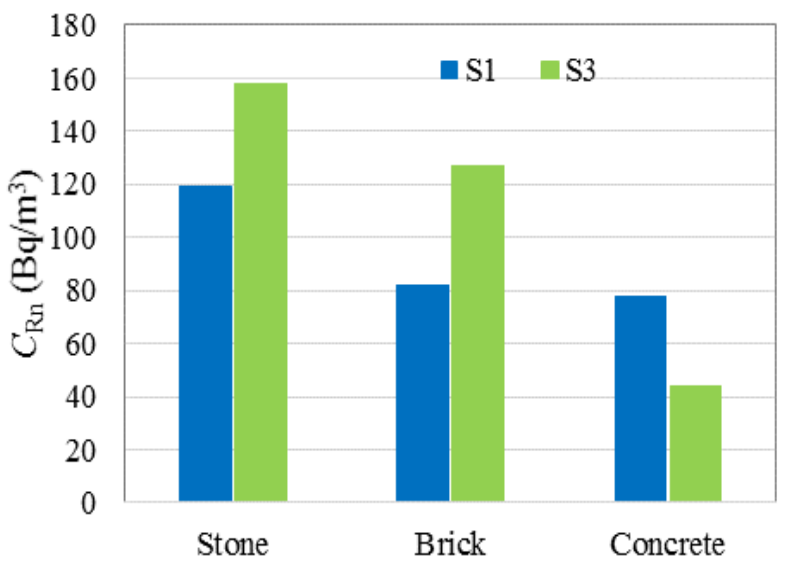

Figure 4. GMs of $C_{\mathrm{Rn}}$ measured in buildings with different dominant building materials

The effects of the type of dominant building materials on $C_{\mathrm{Rn}}$ variations were investigated in $\mathrm{S} 1$ and S3 surveys. Respectively for S1 and S3, the $\mathrm{GM}$ of $C_{\mathrm{Rn}}$ (with GSD in brackets) for buildings built out of stone: $119(2.0) \mathrm{Bq} / \mathrm{m}^{3}$ and 158 (2.41) $\mathrm{Bq} / \mathrm{m}^{3}$; brick $82(1.9) \mathrm{Bq} / \mathrm{m}^{3}$ and $127(2.2) \mathrm{Bq} / \mathrm{m}^{3}$; concrete $78(1.8) \mathrm{Bq} / \mathrm{m}^{3}$ and $44(1.37) \mathrm{Bq} / \mathrm{m}^{3}$ are presented in Figure 4.

\section{Radon seasonal variation}

The GMs of $C_{\mathrm{Rn}}$ (with GSD in brackets) measured in winter, spring summer and autumn were: 115 (2.02) $\mathrm{Bq} / \mathrm{m}^{3}, 72$ (1.97) $\mathrm{Bq} / \mathrm{m}^{3}, 46$ (1.95) $\mathrm{Bq} / \mathrm{m}^{3}, 92$ (2.02) $\mathrm{Bq} / \mathrm{m}^{3}$, respectively for $\mathrm{S} 1$ survey, while for $\mathrm{S} 2$ and $\mathrm{S} 4$ surveys these values were: $76(1.7) \mathrm{Bq} / \mathrm{m}^{3}$ and $114(1.9) \mathrm{Bq} / \mathrm{m}^{3}$ and corresponded for the measurements performed in spring and winter.

\section{Comparison with literature}

For comparison, the results from radon surveys performed in some European countries situated on the Balkan Peninsula are given in Table 3.

Table 3. Results from radon surveys performed in some countries on Balkan Peninsula

\begin{tabular}{|c|c|c|c|c|c|c|}
\hline \multirow[b]{2}{*}{ Country } & \multirow[b]{2}{*}{ Indoor $(\mathrm{N})$} & \multirow{2}{*}{$\begin{array}{l}\text { Period of } \\
\text { detector } \\
\text { exposure } \\
\text { (months) }\end{array}$} & \multicolumn{3}{|c|}{$C_{\mathrm{Rn}}\left(\mathrm{Bq} / \mathrm{m}^{3}\right)$} & \multirow[b]{2}{*}{ Reference } \\
\hline & & & $\operatorname{Max}$ & $\begin{array}{l}\mathrm{AM} \\
(\mathrm{SD})\end{array}$ & $\begin{array}{c}\text { GM } \\
(\mathrm{GSD})\end{array}$ & \\
\hline Serbia/Sokobanja & Dwellings (40) & 12 & 189 & 55 & 43 & $\begin{array}{l}\text { Žunić et al. } \\
2017\end{array}$ \\
\hline $\begin{array}{l}\text { Serbia/Sokobanja } \\
\text { municipality }\end{array}$ & Dwellings (43) & 12 & 230 & $\begin{array}{c}60 \\
(44)\end{array}$ & $\begin{array}{c}49 \\
(1.8)\end{array}$ & $\begin{array}{c}\text { Mishra et al. } \\
2014\end{array}$ \\
\hline Serbia/Niska Banja & Dwellings (65) & & $>6000$ & 1163 & $\begin{array}{l}529 \\
(3.9)\end{array}$ & $\begin{array}{l}\text { Žunić et al. } \\
2007\end{array}$ \\
\hline $\begin{array}{l}\text { Serbia/Krusevac, Brus, } \\
\text { Blace and Kursumlija }\end{array}$ & Dwellings (60) & 3 & 358 & $\begin{array}{c}82.3 \\
(60.6)\end{array}$ & $\begin{array}{l}65.6 \\
(2.1)\end{array}$ & $\begin{array}{l}\text { Vucković et } \\
\text { al. } 2016\end{array}$ \\
\hline Serbia/ Southern part & Schools (207) & $2 \times 6$ & 428 & $\begin{array}{l}118 \\
(78)\end{array}$ & $\begin{array}{c}97 \\
(1.9)\end{array}$ & $\begin{array}{c}\text { Žunić et al. } \\
2013\end{array}$ \\
\hline Serbia /Kragujevac City & $\begin{array}{l}\text { Kindergartens (14) } \\
\text { Schools (28) }\end{array}$ & 3 & 145 & $\begin{array}{l}59.6 \\
(25.6)\end{array}$ & $\begin{array}{c}55.1 \\
(1.18)\end{array}$ & $\begin{array}{l}\text { Stajić et al. } \\
2015\end{array}$ \\
\hline $\begin{array}{l}\text { Kosovo and Metohija/ } \\
\text { South-Easter and Central } \\
\text { part) }\end{array}$ & Dwellings (25) & $2 \times 6$ & 378 & $\begin{array}{l}163 \\
(84)\end{array}$ & $\begin{array}{l}143 \\
(1.7)\end{array}$ & $\begin{array}{l}\text { Gulan et al. } \\
2013\end{array}$ \\
\hline $\begin{array}{l}\text { Kosovo and Metohija/ } \\
\text { whole territory }\end{array}$ & Dwellings (48) & $2 \times 6$ & 1016 & $\begin{array}{c}122 \\
(167)\end{array}$ & $71(2.7)$ & $\begin{array}{l}\text { Gulan et al. } \\
2012\end{array}$ \\
\hline $\begin{array}{l}\text { Republic of Srpska/ } \\
\text { Banja Luka city }\end{array}$ & $\begin{array}{l}\text { Schools (25) } \\
\text { Schools (207) }\end{array}$ & 12 & 549 & $\begin{array}{c}128 \\
(111)\end{array}$ & $\begin{array}{c}99 \\
(1.94)\end{array}$ & $\begin{array}{l}\text { Ćurguz et al. } \\
2015\end{array}$ \\
\hline Bulgaria/Sofia city & Kindergartens (296) & 3 & 1415 & $\begin{array}{c}132 \\
(118)\end{array}$ & $\begin{array}{c}101 \\
(2.08)\end{array}$ & $\begin{array}{c}\text { Ivanova et al. } \\
2014\end{array}$ \\
\hline $\begin{array}{l}\text { Bulgaria/ Sofia city, Sofia } \\
\text { district, Plovdiv and Varna }\end{array}$ & Dwellings (373) & 6 & 3560 & $\begin{array}{c}158 \\
(304)\end{array}$ & $\begin{array}{c}99 \\
(2.25)\end{array}$ & $\begin{array}{c}\text { Ivanova et al. } \\
2013\end{array}$ \\
\hline $\begin{array}{l}\text { Bulgaria/ Kremikovtsi } \\
\text { municipality }\end{array}$ & $\begin{array}{l}\text { Schools and } \\
\text { kindergarten (9) }\end{array}$ & 8 & 1761 & $\begin{array}{c}694 \\
(504)\end{array}$ & $\begin{array}{l}542 \\
(2.06)\end{array}$ & $\begin{array}{l}\text { Vuchkov et } \\
\text { al. } 2013\end{array}$ \\
\hline Greece/Xanthi prefecture & Schools (77) & $8 / 10$ & 958 & $\begin{array}{c}231 \\
(150)\end{array}$ & & $\begin{array}{c}\text { Clouvas et al. } \\
2009\end{array}$ \\
\hline
\end{tabular}




\section{DISCUSSION}

Table 2 summarizes the basic statistics of the $C_{\mathrm{Rn}}$ measurements results obtained in the four surveys implemented in the Republic of Macedonia. The measured $C_{\mathrm{Rn}}$ values were observed to be normally distributed. The main conclusions from S1 were that $C_{\mathrm{Rn}}$ values have shown spatial variability throughout the country territory. The variabilities of $C_{\mathrm{Rn}}$ between country regions (Figure1), as well as within them, were significant. In general, they were mainly affected by regional and local geology features, as well as by the building characteristics. The maximum value of $720 \mathrm{~Bq} / \mathrm{m}^{3}$ reported for $\mathrm{S} 1$ survey was measured in Pelagonia statistical region (Stojanovska et al., 2011a;). In order to clarify this high value, a small measuring champagn in Kruševo (a small town in the Pelagonia statistical region) was conducted after S1 survey. The elevated values for $C_{\mathrm{Rn}}$ and natural radionuclides content in top soil were related to Amphibole-biotite granodiorite lithostratigraphy (Stojanovska et al. 2012).

Certain differences between results in the surveys given in the Table 2 are noticeable. They originated from the differences in each study design. For example, the S1 survey was conducted in dwellings distributed throughout the whole country territory, just like S4, but in the S4 measurements were organized only on the ground floor rooms. For these reasons, the $C_{\mathrm{Rn}}$ values in $\mathrm{S} 4$ were higher than in $\mathrm{S} 1$ survey. It is interesting to note that in these two studies the percentage of dwellings that exceeds the National action level of $400 \mathrm{~Bq} / \mathrm{m}^{3}$ is the same and it is $2 \%$ in both cases. Subsequently, the S2 survey was done on the ground floor in the Vardar zone, where from the previous knowledge elevated $C_{\mathrm{Rn}}$ in that area was not expected. The results confirmed the same, the obtained $C_{\mathrm{Rn}}$ results in $\mathrm{S} 2$ were lower than those corresponding to $\mathrm{S} 1$, also the maximum measured value was $<400 \mathrm{~Bq} / \mathrm{m}^{3}$. The higher $C_{\mathrm{Rn}}$ in Table 2 corresponds to $\mathrm{S} 3$ survey. In this case, the larger part of the investigated region lies down in KratovskaZletovska area, where bed rocks are from the volcanic origin. Detailed investigations of the $C_{\mathrm{Rn}}$ have been shown that the elevated $C_{\mathrm{Rn}}$ was in relation with tuff, tuffite of andesite and latite (Stojanovska et al., 2016). The existence of a connection between natural radioactivity and geology on the basis of broader research has been confirmed, not only due to indoor radon, but also to indoor thoron (Stojanovska et al. 2013) and ${ }^{226} \mathrm{Ra}$ (Bossew et al. 2013) in spatial variability analysis of surface soils.

The effect of the building floor on annual $C_{\mathrm{Rn}}$ variations can be seen in Figure 2. The GMs values of $C_{\mathrm{Rn}}$ measured in the ground floor in all surveys were higher than this in the first and second floors. On the other hand, the difference between the first and second floor concentrations is not significant (Stojanovska et al., 2011a;). Also the GMs values that correspond to the measurements in ground floors over the entire territory of the country (S1 and S4) are practically the same (Figure 2). Opposite to this, the results from S2 survey are lower and from S3 survey are higher than the GMs in S1 and $\mathrm{S} 4$ surveys. The GMs of the $C_{\mathrm{Rn}}$ measurements performed in buildings without basements are lower than in buildings with basements (Figure 3). Furthermore, the GMs of $C_{\mathrm{Rn}}$ in buildings with basements cover wider range than the GMs of $C_{\mathrm{Rn}}$ in buildings without basement. So, the spatial distribution of $C_{\mathrm{Rn}}$ in the buildings with basements is practically uniform, while in those without basements where the inhabitants are in direct contact with the ground the $C_{\mathrm{Rn}}$ varied considerably. These variations are associated with different influences of the geogenic radon over the different parts of the country.

From Figure 4, it can be concluded that the higher values of $C_{\mathrm{Rn}}$ refer to the stone buildings. On the same figure, the differences between the $C_{\mathrm{Rn}}$ measured in buildings made of brick and concrete are not noticeable for the S1 survey. On the contrary, the higher $C_{\mathrm{Rn}}$ in buildings built from bricks than these from concrete in the Kratovo-Zletovska area implicate the use of local building materials.

The fact that the global trend to improve energy efficiency in the buildings increase the $C_{\mathrm{Rn}}$ was confirmed in the S3 survey where the impact of new windows in buildings on $C_{\mathrm{Rn}}$ variations was studied. The analysis showed that the $C_{\mathrm{Rn}}$ in buildings with new windows was twice higher in comparison to $C_{\mathrm{Rn}}$ in buildings with wooden windows $\left(\mathrm{GM}=110(2.13) \mathrm{Bq} / \mathrm{m}^{3}\right)$. In the same survey, the environmental impact on $C_{\mathrm{Rn}}$ was examined, but it turned out that there was no difference between urban and rural areas (Stojanovska et al. 2016a).

That long term measurements of $C_{\mathrm{Rn}}$ in schools can be representative for a given region as well as for dwellings, even the different occupation time in schools was founded in the S3 survey. The results of annual $C_{\mathrm{Rn}}$ measurements in schools, dwellings and kindergartens were not different (Stojanovska et al., 2016a). There are also no differences between the results of $C_{\mathrm{Rn}}$ in schools when they are based on the annual measurements (12 months) and when they are in the period exempt from the summer holiday (9 months) (Stojanovska et al., 2016b).

The $C_{\mathrm{Rn}}$ seasonal variations are presented in Figure 5. The results clearly showed higher $C_{\mathrm{Rn}}$ for 
the winter and autumn periods compared to spring and summer. The latter could be ascribed to the fact that during the colder months the buildings are heated, which creates a higher difference in pressure between the soil and the building. On the other hand, in order to save energy in cold periods, the inhabitants keep windows closed. The seasonal measurements in S1 survey were used to developed seasonal correction factors for annual $C_{\mathrm{Rn}}$ assessment due to $C_{\mathrm{Rn}}$ measurements in one season. The regional variability of the correction factor was confirmed only for the measurements in autumn (Stojanovska et al., 2011b). Applying the seasonal correction on measurements in winter season: the relative uncertainty budget of the annual $C_{\mathrm{Rn}}$ increased only for $3 \%$ as well as the regional variability over the country is not affected significantly (Stojanovska et al., 2017).

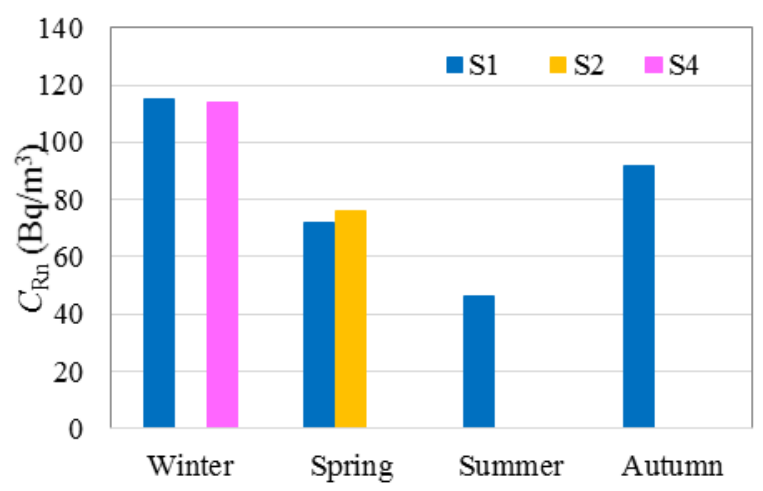

Figure 5. GM of $C_{\mathrm{Rn}}$ measured in different season

Finally we compared the obtained annual $C_{\mathrm{Rn}}$ in our research with that published in the literature. In general, the obtained GMs of $C_{\mathrm{Rn}}$ in all surveys (Table 2) were higher than the worldwide GM of $30 \mathrm{~Bq} / \mathrm{m}^{3}$ reported in the UNSCER 2000 report. On the other hand, the both mean radon concentrations expressed with AM and GM, together with its deviations, are more or less typical as the radon levels reported for some other countries in the Balkan Peninsula (Table 3).

\section{CONCLUSION}

Spatial variations of $C_{\mathrm{Rn}}$ have been proven in all radon studies conducted in the Republic of Macedonia. In general, in the regions where bed rocks are from volcanic origin the $C_{\mathrm{Rn}}$ is higher in comparison with the other parts of the country. Also, the characteristics of the buildings have a significant effect on $C_{\mathrm{Rn}}$ variations. The highest concentrations were measured in buildings on the ground floor without basements built with stone. When new windows are installed in such a building, the $C_{\mathrm{Rn}}$ increases additionally. The results show that in the few percents of buildings in Macedonia the $C_{\mathrm{Rn}}$ exceeds the permissible level and they have to be remediated. Further research in this field should be include health and building professionals in order to create an effective radon protection program.

\section{REFERENCE}

[1] F. Bochicchio, Z. S. Žunić, C. Carpentieri, et al., Radon in indoor air of primary schools: a systematic survey to evaluate factors affecting radon concentration levels and their variability, Indoor Air, 24 (2014), pp. 315-326.

[2] P. Bossew, Z. S. Žunić, Z. Stojanovska et al., Geographical distribution of the mean radon concentrations in primary schools of Southern Serbia - application of geostatistical methods, $J$ Environ. Radioact., 127 (2013), pp. 141-148.

[3] P. Bossew, Z. Stojanovska, Z. S. Žunić et al., Prediction of indoor radon risk from radium concentration in soil: Republic of Macedonia case study, Rom. J. Phys., 58 (2013), pp. 29-43.

[4] C. Carpentieri, Z. S. Žunić, V. Carelli et al., Assessment of long-term radon concentration measurement precision in field conditions (Serbian schools) for a survey carried out by an international collaboration, Radiat. Prot. Dosim., 145 (2011), pp. 305-311.

[5] Census of Population, Households and Dwellings in the Republic of Macedonia. Republic of Macedonia State Statistical Office, 2002.

[6] A. Clouvas, G. Takoudis, S. Xanthos et al., Indoor radon measurements in areas of Northern Greece with relatively high indoor radon concentrations, Radiat. Prot. Dosim., 136 (2) (2009), pp. 127-131.

[7] Z. Ćurguz, Z. S. Žunić, T. Tollefsen et al., Active and passive radon concentration measurements and first-step mapping in schools of Banja Luka, Republic of Srpska, Rom. J. Phys., 58 (2013), pp. 90-98.

[8] Z. Ćurguz, Z. Stojanovska, Z. S. Žunić et al., Longterm measurements of radon, thoron and their airborne progeny in 25 schools in Republic of Srpska, J. Environ. Radioact., 148 (2015), pp.163-169.

[9] S. Darby, D. Hill, A. Auvinen et al., Radon in homes and risk of lung cancer: Collaborative analysis of individual data from 13 European case-control studies. 2005; BMJ 330.7485 223-0.

[10] L. Gulan, G. Milić, P. Bossew et al., Field experience on indoor radon, thoron and their progenies with solid-state detectors in a survey of Kosovo and Metohija (Balkan region). Radiat. Prot. Dosim., 152 (1-3) (2012), pp. 189-197. 
[11] L. Gulan, F. Bochicchio, C. Carpentieri et al., High annual radon concentration in dwellings and natural radioactivity content in nearby soil in some rural areas of Kosovo and Metohija (Balkan region), Nucl. Technol. Radiat., 28 (1) (2013), pp. 60-67.

[12] K. Ivanova, Z. Stojanovska, V. Badulin et al., Pilot survey of indoor radon in the dwellings of Bulgaria, Radiat. Prot. Dosim., 157 (4) (2013), pp. 594-599.

[13] K. Ivanova, Z. Stojanovska, M. Tsenova et al., Measurement of indoor radon concentration in kindergartens in Sofia, Bulgaria, Radiat. Prot. Dosim., 162 (1-2):2014; pp. 163-166.

[14] K. Ivanova, Z. Stojanovska, V. Badulin et al., Screening for risk assessment around closed uranium mining sites, Radioprotection, 51 (3) (2016), pp. 193-198.

[15] P. Kolarž, J. Vaupotič, I. Kobal et al., Thoron, radon and air ions spatial distribution in indoor air, J. Environ. Radioact., 173 (2017), pp. 70-74.

[16] B. Kunovska, K. Ivanova, Z. Stojanovska et al., Measurements of radon concentration in soil gas of urban areas, Bulgaria, Rom. J. Phys., 58 (2013), pp. 172-179.

[17] R. Mishra, Z. S. Žunić, G. Venoso et al., An evaluation of thoron (and radon) equilibrium factor close to walls based on long-term measurements in dwellings, Radiat. Prot. Dosim., 160 (1-3) (2014), pp.164-168.

[18] G. Nafezi, A. Gregorič, J. Vaupotič et al., Radon levels and doses in dwellings in two villages in Kosovo, affected by depleted uranium, Radiat. Prot. Dosim., 158 (3) (2014), pp. 331-339.

[19] D. Nikolopoulos, S. Kottou, A. Louizi et al., Factors Affecting Indoor Radon Concentrations of Greek Dwellings through Multivariate Statistics First Approach., J. Phys. Chem. Biophys., 4 (2014), p. 145

[20] J. M. Stajić, B. Milenković, D. Nikezić, Radon concentrations in schools and kindergartens in Kragujevac City, Central Serbia, CSAWAC, 43 (10) (2015), pp. 1357-1442.

[21] Z. Stojanovska, J. Januseski, B. Boev et al., Indoor exposure of population to radon in the FYR of Macedonia, Radiat. Prot. Dosim., 148(2) (2011a), pp. 162-167.

[22] Z. Stojanovska, J. Januseski, P. Bossew et al., Seasonal indoor radon concentration in FYR of Macedonia, Radiat. Meas., 46 (6-7) (2011b), pp. 602-610.

[23] Z. Stojanovska, J. Januseski, B. Boev et al., Indoor radon and soil radioactivity in Krusevo, Republic of Macedonia, Geologica Macedonica, 3 (2012), pp. 331-336.
[24] Z. Stojanovska, P. Bossew, S. Tokonami et al., National survey of indoor thoron concentration in FYR of Macedonia (continental Europe - Balkan region), Radiat. Meas., 49(1) (2013), pp. 57-66.

[25] Z. Stojanovska, Z. S. Žunić, P. Bossew et al., Results from time integrated measurements of indoor radon, thoron and their decay product concentrations in schools in the Republic of Macedonia, Radiat. Prot. Dosim., 162 (1-2) (2014), pp. 152-156.

[26] Z. Stojanovska, B. Boev, Z. S. Žunić et al., Variation of indoor radon concentration and ambient dose equivalent rate in different outdoor and indoor environments, Radiat. Environ. Biophys., 55(2) (2016a), pp. 171-183.

[27] Z. Stojanovska, B. Boev, Z. S. Žunić et al., Results of radon CR-39 detectors exposed in schools due two different long-term periods, Nukleonika, 61(3) (2016b), pp. 385-389.

[28] Z. Stojanovska, K. Ivanova, P. Bossew et al., Prediction of long-term indoor radon concentration based on short-term measurements, Nucl. Technol. Radiat. 32 (1) (2017), pp. 77-84.

[29] J. Vaupotič, I. Celikovic, N. Smrekar, Z. S. Žunić, I. Kobal, Concentrations of ${ }^{222} R n$ and ${ }^{220} R n$ in Indoor Air, Acta Chimica Slovenica 55 (2008), pp. 160-165.

[30] J. Vaupotič, Radon in kindergartens and schools a review. In Z. Li, \& Ch. Feng (Eds.), Handbook of radon: properties applications and health New York: Nova Science Publishers. 2012; 477-524.

[31] J. Vaupotič, T. Streil, S. Tokonami et al., Diurnal variations of radon and thoron activity concentrations and effective doses in dwellings in Niska Banja, Radiat. Prot. Dosim., 157 (2013), pp. 375-382.

[32] B. Vucković, L. Gulan, B. Milenković et al., Indoor radon and thoron concentrations in some towns of central and South Serbia, J. Environ. Manage., 183 (3) (2016), pp. 938-944.

[33] D. Vuchkov, K. Ivanova, Z. Stojanovska et al., Radon measurement in schools and kindergartens (Kremikovtsi Municipality, Bulgaria), Rom. J. Phys, 58 (2013), pp. 328-335.

[34] UNSCEAR, 2000. Sources and Effects of Ionizing Radiation. United Nations Scientific Committee on the Effect of Atomic Radiation 2000. United Nations, New York.

[35] World Health Organization. Handbook on Indoor Radon: A Public Health Perspective. WHO Press, Geneva. ISBN 978924154767 3: Eds. Zeeb, H. and Shannoun, F. 2009.

[36] I. Yarmoshenko, A. Vasilyev, G. Malinovsky et al., Variance of indoor radon concentration: Major influencing factors, Sci Total Environ, 541 (2016), pp. $155-160$. 
[37] Z. S. Žunić, I. Yarmoshenko, A. Birovljev et al., Radon Survey in the High Natural Radiation Region of Niska Banja, Serbia, $J$ Environ. Radioact., 92(3) (2007), pp. 165-174.

[38] Z. S. Žunić, I. Celikovic, S. Tokonami et al., Collaborative investigations on thoron and radon in some rural communities of Balkans, Radiat Prot Dosim., 141 (2010), pp. 346-350.

[39] Z. S. Žunić, C. Carpentieri, Z. Stojanovska et al., Some results of a radon survey in 207 Serbian schools, Rom. J. Phys, 58 (2013), pp. 320-327.

[40] Z. S. Žunić, P. Ujic, L. Nad et al., High variability of indoor radon concentrations in uraniferous bedrock areas in the Balkan region, Appl. Radiat. Isotop., 94 (2014), pp. 328-337.

[41] Z. S. Žunić, P. Bossew, F. Bochicchio et al., The relation between radon in schools and in dwellings: A case study in a rural region of Southern Serbia, J. Environ. Radioact., 167(1) (2017a;), pp. 188-200.

[42] Z. S. Žunić, Z. Stojanovska, N. Veselinović et al., Indoor radon, thoron and their progeny concentrations in high thoron rural Serbia environments. Radiat Prot Dosim., 2017b.

DOI: doi.org/10.1093/rpd/ncx167.

\title{
РЕЗУЛАТИ ОД МЕРЕЊАТА НА РАДОН ВО ЗАТВОРЕН ПРОСТОР НИЗ РЕПУБЛИКА МАКЕДОНИЈА: ПРЕГЛЕД
}

\author{
Зденка Стојановска ${ }^{1}$, Блажо Боев ${ }^{2}$, Иван Боев $^{2}$
}

\footnotetext{
${ }^{1}$ Универзитет Гоце Делчев, Факултет за медицински науки, Штип, Република Македонија

${ }^{2}$ Универзитет Гоце Делчев, Факултет за природни и технички науки, Штип, Република Македонија
}

Акумулираниот радон и неговите продукти со кусо време на распаѓање во затворен простор се главен природен извор на озрачување на населението. Ефектите врз здравјето, како и бројните природни и вештачки фактори кои влијаат врз акумулацијата на радон во затворен простор, се еден од мотивите за научниот интерес за радонот. Следејќи го овој глобален тренд на Балконот, вклучувајќк ја и Република Македонија, во последната деценија беа спроведени многу истражувања на радонот во затворен простор. Овој труд дава преглед на веќе објавените резултати од спроведените мерења на концентрацииите на радон во простории низ Република Македонија користејќи нуклеарни трагови детектори. Тој дава основни информации за просторната и временската варијабилност на радонот во затворен простор низ територијата на земјата, проследено со опис на ефектите од некои фактори кои влијаат врз тие варијации. Намерата на прегледот е: да ги организира и да ги искоментира достапните резултати за радонот во затворен простор, со цел да се даде јасна слика за досега спроведените истражувања, да се истакне потребата од продолжување на пообемно истражување на радонот во просториите на работните места, мотивирање на градежните професионалци за креирање колку што е можно повеќе мерки за ублажување и превенција од зголемини концентрации на радон во затворен простор, мотивирање на здравствените работници за епидемиолошки студии итн.

Клучни зборови: радон во затворен простор; просторни варијации; временски варијации; геологија; карактеристики на зграда 